\title{
COPPER TOLERANCE, PROTEIN AND CATALYTIC ACTIVITY IN PHYTOPATHOGENIC FUNGUS ALTERNARIA ALTERNATA
}

SHOAIB A. ${ }^{*}$

AKHTAR S.

AKHTAR N.

Received: 24/09/2014

Accepted: $27 / 08 / 2015$

Available online: 29/09/2015
Institute of Agricultural Sciences

University of the Punjab, Lahore, Pakistan

\section{ABSTRACT}

In vitro tolerance of soil borne phytopathogenic fungus i.e. Alternaria alternata in terms of growth, physiology and metal uptake capacity against different doses of copper $[\mathrm{Cu}(\mathrm{II})]$ metal was assessed. In preliminary growth experiments, nitrate, chloride and sulphate of $\mathrm{Cu}(\mathrm{II})$ were amended in seven different concentrations viz. 25, $50,75,80,85,90$ and $100 \mathrm{ppm}$ in nutritive agar medium along with fungus inoculum. Amongst three salts, the maximum inhibition in radial growth of the fungus was observed with increasing concentrations of copper salts in order of: $\mathrm{CuSO}_{4}>\mathrm{CuNO}_{3}>\mathrm{CuCl}_{2}$. Further trials were conducted in nutritive broth with four different concentrations $(25,50,75$ and $100 \mathrm{ppm})$ of copper sulphate to assess growth inhibition, metal accumulation, protein and catalase activity in the fungus biomass. It was found that fungus dry biomass was significantly declined by $70-99 \%$ along with net metal accumulation of $40 \%$ with increasing metal concentrations. Total protein contents and catalase activity was considerably increased up to 2-5 and 2-3 folds, respectively with increase in metal concentration from 25-100 ppm and incubation period from 48, 72 and 96 hours over control. Present study concludes that $A$. alternata was able to tolerate up to $90 \mathrm{ppm}$ of copper, therefore it is imperative to consider fungus metal tolerance range during fungicide formulations.

Keyword: Heavy metal, Cu(II), Fungus, Physiology, Microorganism, Oxidative stress

\section{Introduction}

Copper $(\mathrm{Cu})$ is essential micronutrient required for normal growth of plants but toxic when present in excess. $\mathrm{Cu}$ toxicity results from the formation of reactive oxygen species or from the interaction with proteins impairing key cellular processes, inactivating enzymes and disturbing protein structure (Yruela, 2009). Although $\mathrm{Cu}$ is a trace element, owing to anthropogenic activities, $\mathrm{Cu}$ toxicity has become an agricultural and environmental problem in recent years (Cornejo et al., 2013). Generally, a concentration range of I-10 $\mu \mathrm{M}$ is considered as essential and above $10 \mathrm{mM}$ is described as toxic for microorganisms (Abe et al., 2001). Above the permissible limit $\mathrm{Cu}$ toxicity is mainly occurred due to changes in enzyme active sites, interactions with nucleic acids and oxidation of membrane components and their relevant processes (Plum et al., 2010).

A wide range of copper containing pesticides are utilized in the agriculture against phytopathogenic microorganisms. Therefore, soil copper level is gradually and regularly increasing thus imparting ecotoxicological effects. Cur exhibits the potential to alter the soil ecological balance either by directly

Shoaib A., Akhtar S. and Akhtar N. (2015), Copper tolerance, protein and catalytic activity in phytopathogenic fungus Alternaria alternate, Global NEST Journal, 17(4), 664-672. 
affecting non target soil organisms or by changing the soil physic-chemical characteristics, which in turn dictates the composition of soil biota. Consequently, the activity, ecology and population of micro- and macro-organisms adversely affected (Oliveira and Pampulha, 2006). Investigations regarding metal polluted soils have documented reduction in microbial community size, composition and diversity along with decline in organic matter mineralization due to increase in metal concentration (Chander and Brookes, 1991; Konopka et al., 1999; Rudawska et al., 2000). It was also observed that spore of many beneficial fungi fail to germinate under metal-polluted soil (Gattai et al., 2011). Whereas, reduction in number of perithecia and spores of fungi with damage to seta, conidiophores and phialides was observed by Hefnawy et al. (2009). There are reports that showed negative consequences of $\mathrm{Cu}$-based pesticides on growth and survival of plant pathogenic fungi as well. Accordingly low dose of such pesticides stress and weaken the pathogen and render its propagules more susceptible to subsequent attack (Islam et al., 2011). Therefore, it is imperative to assess tolerance level of microorganism against copper-based pesticide to assess optimized use of pesticides.

So far, many saprotrophic fungi are very sensitive to heavy metal stress and their extra cellular enzymes are damaged by metal stresses that are otherwise helpful in nutrient acquisition (Petr, 2010). Whereas, there are certain fungi that have the ability to withstand and grow under increasing concentrations of metal (Al-Abboud and Alawlaq, 2011). Mehta et al. (2010) documented that strain of $F$. oxysporum can tolerate $600 \mathrm{ppm}$ of $\mathrm{Cu}$ in growth medium. Al-Abboud and Alawlaqi (2011) findings revealed that Aspergillus terreus and A. alternata can tolerate up to $1000 \mathrm{ppm}$ of $\mathrm{Cu}$. Fungi, have developed mechanisms to combat with toxic heavy metals, thus created resistance against metal-based fungicides. Number of possible interactions between toxic metals and fungi has been reported. Fungi have developed mechanisms to combat with toxic heavy metals, thus creates resistance against metal-based fungicides. Some have observed binding/complexion and/or precipitation of metal ions with organic acids, proteins, melanin secreted by fungi (Gadd, 1993; Baldrian, 2003). Some have documented bindings of metal ions with functional groups on fungal cell walls (Shoaib et al., 2013), some agreed with transport of metal cations (Clemens et al., 2002) and chemical transformation of metals (Gadd, 1993). However, there are reports that indicated that internal compartmentalization to detoxify pollutants is strategy adapted by fungi to translocate surplus $\mathrm{Cu}$ to subcellular compartments (Cornejo et al., 2013). They further stated that survival of many fungi like arbuscular mycorrhizal one in soil is due to accumulation of heavy metal in their spores that is actually linked with production of oxalic acid that precipitates the metal oxalate rendering $\mathrm{Cu}$ inert. Moreover, excessive heavy metals are known to induce oxidative stress in fungi by generating high concentrations of toxic super oxide radical that results in increased activity of detoxifying enzymes like catalase (Choudhary et al., 2007). Changes in the activity of these defense systems have been proposed as biomarkers for contaminant-mediated pro-oxidant challenge (Furat and Kargin, 2010).

Alternaria alternata (Fries) Keissler is a saprophytic, opportunistic pathogen belongs to black pigmented mould (Dematiaceae), that has been reported to cause leaf spot and other diseases on over 380 host species of plant. The achievement of in vitro tolerance of soil borne phytopathogenic fungus Alternaria alternata in terms of growth, physiology and metal uptake capacity against different doses of copper is an important goal due to the high rates of Copper ( $\mathrm{Cu}$ ) use in agricultural sector.

\section{Materials and methods}

\subsubsection{Procurement and culturing of the fungus}

The pure culture of A. alternata (Accession \# 0092) was obtained from First Fungal Culture Bank of Pakistan, Institute of Agricultural Sciences, University of the Punjab, Lahore, Pakistan. The fungal culture was sub cultured, maintained on 2\% MEA (Malt extract agar) medium and stored at $4^{\circ} \mathrm{C}$ as a stock for further experiments. 


\subsection{Preparation of metal salt solution}

Stock solutions $(1000 \mathrm{ppm})$ of copper nitrate $\left(\mathrm{CuNO}_{3}\right)$, copper sulphate $\left(\mathrm{CuSO}_{4} .5 \mathrm{H}_{2} \mathrm{O}\right)$ and copper chloride $\left(\mathrm{CuCl}_{2}\right)$ (Merk, Germany) were prepared separately by dissolving $187.6 \mathrm{~g}, 159.2 \mathrm{~g}$ and $134.5 \mathrm{~g}$ salts, respectively in $1000 \mathrm{ml}$ of double distilled water. Further dilutions of 25, 50, 75, 80, 85, 90 and 100 ppm were made from the stock solutions for further experimentations.

\subsection{Fungal growth assays with different salts of copper in agar medium}

Basal medium for the growth of fungus was prepared by adding Malt extract agar (MEA) in water followed by autoclaving. Chloromycetin ( $250 \mathrm{mg}$ capsule in $100 \mathrm{ml}$ of medium) was added to avoid bacterial contamination. Each of seven concentrations i.e. $25,50, \ldots \ldots \ldots, 100 \mathrm{ppm}$ of each three salt of metal was added under aseptic conditions and media were again autoclaved. $\mathrm{pH}$ of medium was maintained at $6(0.5 \mathrm{M} \mathrm{NaOH}$ and $0.5 \mathrm{M} \mathrm{HCl}$ was used to adjust $\mathrm{pH}$ in each flask). The metal-amended medium in each Petri dish were inoculated aseptically with $5 \mathrm{~mm}$ (diameter) inoculum-disc of the test fungus, obtained from healthy growing fungal cultures and incubated at $25 \pm 2{ }^{\circ} \mathrm{C}$ for 7 days. The medium with inoculums disc but without any metal served as control. Radial colony diameter of fungus was measured in $\mathrm{cm}$ and percentage inhibition of mycelial growth by the metal concentrations was calculated using the formula:

$$
\% \mathrm{MG}=D C-D T / D T \times 100
$$

Where: \%MG = \% Inhibition of mycelial growth; DC = diameter of control; DT = diameter of test.

Amongst three salts, copper sulphate exhibited maximum inhibition in fungal radial growth; therefore further experiments were conducted in broth to assess effect of copper sulphate on biomass production, metal accumulation and biochemical changes in fungal biomass.

\subsection{Fungus growth assays with copper sulphate in broth}

Effect of aqueous solution of copper sulphate on the fungal biomass production was determined in $2 \%$ Malt extract broth. In basal medium, copper sulphate solution was added to make the final concentration of 25 , 50, 75 and 100 ppm. For control treatment, sterilized distilled water was added instead of metal solution. Inoculum discs of $5 \mathrm{~mm}$ diameter from one week actively growing fungus was transferred to treatment as well as control flasks under aseptic conditions and incubated at $25 \pm 2{ }^{\circ} \mathrm{C}$ for 7 days. The mycelial biomass was collected on pre-weighed filter papers and fresh weight was determined. For dry biomass determination, filtered biomass was oven dried overnight at $60^{\circ} \mathrm{C}$.

\subsection{Estimation of copper accumulation by the fungal biomass}

Dried powdered samples $(0.5 \mathrm{~g})$ of fungal mycelia from each of four metal treatments were digested with 10 $\mathrm{ml}$ of $\mathrm{HNO}_{3}$ followed by analysis on atomic absorption spectrophotometer for residual copper. Before proceeding for analysis, the samples containing copper were appropriately diluted with double distilled deionized water to ensure that the metal ion concentrations in the sample were linearly dependent on the absorbance detected

\subsection{Assessment of protein and catalytic activity in the fungal biomass}

Protein and catalytic activities in the fungus biomass were determined after 48, 72 and 96 hours of the growth. The fungus was cultivated in metal amended liquid medium with each of four different concentrations of 25, 50, 75 and 100 ppm of copper sulphate in similar way as described in above section.

Total protein content was assayed according to the Foiln Lowry's method (1951). Alkaline sodium carbonate solution was prepared by adding $2 \% \mathrm{Na}_{2} \mathrm{CO}_{3}$ in $0.1 \mathrm{~N} \mathrm{NaOH}$ and was marked as Solution 1. Copper sulphate: sodium tartarate solution was prepared by adding $0.5 \% \mathrm{CuSO}_{4}$ in $1 \% \mathrm{Na}$ tartarate and was marked as Solution 2. Alkaline solution was prepared by mixing $50 \mathrm{ml}$ of Solution: 1 and $1 \mathrm{ml}$ of Solution: 2. About $500 \mathrm{mg}$ of 
fungal mycelium was homogenate in $1 \mathrm{ml}$ of alkaline solution. The mixture was kept at the room temperature for 10-15 minutes followed by addition of $0.5 \mathrm{ml}$ of diluted Folin Ciocalteau reagent. After 30 minutes, the optical density was noted by spectrophotometer at $\mathrm{OD}_{750} \mathrm{~nm}$.

The catalase activity of fungus was assayed by following the modified method as described by Sinha (1972). In brief, $500 \mathrm{mg}$ of fungal mycelium was homogenate in the $2 \mathrm{ml}$ of reaction mixture $(1.0 \mathrm{ml}$ of phosphate buffer, $0.5 \mathrm{ml} \mathrm{H} \mathrm{O}_{2}$ diluted with $0.5 \mathrm{ml}$ of distilled $\mathrm{H}_{2} \mathrm{O}$ ). To $100 \mu \mathrm{L}$ of cell lysate, peroxide reaction mixture $\left(30 \% \mathrm{H}_{2} \mathrm{O}_{2}, 0.1 \mathrm{M}\right.$ sodium phosphate) was added and incubated at $25{ }^{\circ} \mathrm{C}$ for 10 minutes. Reaction was terminated by adding $2 \mathrm{ml}$ of potassium dichromate-acetic acid reagent (2.5\% aqueous potassium chromate in glacial acetic acid). The samples were kept at $100^{\circ} \mathrm{C}$ for 15 minutes and then brought to room temperature. $A_{570}$ was recorded. Catalase activity was calculated as follows:

$$
\% \text { decrease }=\left(A_{570} \text { Blank }-A_{570} \text { Treatment } /\left[A_{570} \text { Blank }\right]\right) \times 100
$$

The concentration of catalase was expressed as Umol $\mathrm{min}^{-1} \mathrm{mg}^{-1}$ protein.

\subsection{Statistical analysis}

Each experiment was repeated three times in completely randomized design. Data obtained from different treatments were compared through mean values. All means were tested for a significant difference was analyzed through analysis of variance technique and one way-ANOVA (Steel et al., 1997).

\section{Results and Discussion}

\subsection{Fungal growth assays with different salts of copper in agar medium}

The results in Table 1 revealed that fungal radial growth $(\mathrm{cm})$ was significantly decreased due to either chlorate, sulphate or nitrate of $\mathrm{Cu}$ amended in seven different concentrations $(25,50,75,80,85,90$ and 100 $\mathrm{ppm}$ ) as compared to control. While, increasing concentration of each metal slat exhibited more significant inhibition in the fungus diameter, therefore the maximum MIC values were recorded at the highest concentrations ( 85 to $100 \mathrm{ppm}$ ). Amongst three slats, $\mathrm{CuSO}_{4}$ showed the highly significant and maximum inhibition in the radial growth of the fungus at each of the tested concentration. Whereas, maximum

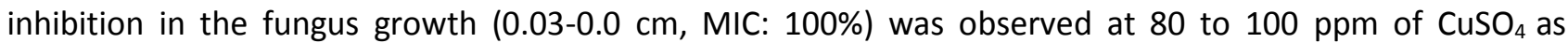
compared to control and rest of metal salts. The radius of fungal mat was negligible $(0.06 \mathrm{~cm} \pm 1)$ at $90 \mathrm{ppm}$ in $\mathrm{CuCl}_{2}$ and 85 ppm in $\mathrm{CuNO}_{3}$ with 100\% MIC, while at 100 ppm no growth of test fungus was observed.

Fungus growth assays in agar medium resulted in significant inhibition in its radial growth with all three salts of $\mathrm{Cu}\left(\mathrm{SO}_{4}, \mathrm{NO}_{3}\right.$ and $\left.\mathrm{Cl}_{2}\right)$. Copper and its compounds have been shown to effectively kill a wide range of fungi (Borkow and Gabbay, 2009) and reduction in the growth rate is a typical response of fungi to toxicants (Gadd, 1993). The inherent toxicity of $\mathrm{Cu}$ due to its redox cycling between $\mathrm{Cu}^{2+}$ and $\mathrm{Cu}^{1+}$ can catalyze the production of highly reactive hydroxyl radicals, which can subsequently damage lipids, proteins, DNA and other biomolecules. Alterations in the conformational structure of nucleic acids and proteins likely to interfere in oxidative phosphorylation and osmotic balance along with inhibition in enzyme functioning due to high affinity of metal with enzyme active sites (sulphahydral and thiolgroupa) (Gadd, 1993; Levinskaite, 2001). The overall change in fungal biochemistry probably consequences with inhibition in fungal sporulation and mycelial growth. $\mathrm{CuSO}_{4}$ was found to exhibit the highest reduction in fungus growth in comparison to rest of two salts. The difference in solubility, electron configuration, ionic radius and other chemical properties of $\mathrm{SO}_{4}, \mathrm{NO}_{3}$ and $\mathrm{Cl}_{2}$ could possibly aid in their ability to differentially bind on functional groups in fungi along with induction of defence mechanism (metallothionein and glutamyl peptide) (Levinskaite, 2001; Pečiulytė and Dirginčiutè-Volodkienè, 2012). The toxic effect of the each metal salt was increased with elevating concentration in the growth medium (Collin-Hanse et al., 2005; Borkow and Gabbay, 2009). At low concentration, fungus might tolerate metal due to the increased efflux and metal immobilization. Toxicity 
with increasing metal concentration might occur through the displacement of essential metals from their native binding sites. Durate et al. (2004) noted that heavy metal concentration and exposure time inhibited fungal production and fungal reproduction by either stimulating or inhibiting sporulation rates of fungi.

Based on fungus growth assays with three slats of $\mathrm{Cu}$ in agar medium, the inhibition in the fungal growth trend was observed in order of: $\mathrm{CuSO}_{4}>\mathrm{CuNO}_{3}>\mathrm{CuCl}_{2}$, therefore further fungal assays in broth were conducted using $\mathrm{CuSO}_{4}$ only.

Table 1. Effect of different salts on the radial growth $(\mathrm{cm})$ of $A$. altermata

\begin{tabular}{|c|c|c|c|c|c|c|c|}
\hline \multirow{2}{*}{ Metal Salts } & \multicolumn{7}{|c|}{ Radial growth $(\mathrm{cm})$ of $A$. altermata } \\
\hline & $25 \mathrm{ppm}$ & 50 ppm & 75 ppm & 80 ppm & 85 ppm & 90 ppm & $100 \mathrm{pm}$ \\
\hline $\mathrm{CuCl}_{2}$ & $\begin{array}{c}6 . \pm 0.12 \\
a\end{array}$ & $\begin{array}{c}4.1 \pm 0.12 \\
\text { b }\end{array}$ & $\begin{array}{c}1.4 \pm 0.18 \\
\text { c }\end{array}$ & $\begin{array}{c}0.98 \pm 0.06 \\
\text { d }\end{array}$ & $\begin{array}{c}0.23 \pm 0.01 \\
\text { e }\end{array}$ & $\begin{array}{c}0.01 \pm 0 \\
f\end{array}$ & $\begin{array}{c}0 \pm 0 \\
\text { g }\end{array}$ \\
\hline $\mathrm{CuNO}_{3}$ & $\begin{array}{c}3.43 \pm 0.09 \\
\text { a }\end{array}$ & $\begin{array}{c}2.3 \pm 0.12 \\
\text { b }\end{array}$ & $\begin{array}{c}1.4 \pm 0.1 \\
\text { c }\end{array}$ & $\begin{array}{c}0.77 \pm 0.05 \\
\text { d }\end{array}$ & $\begin{array}{c}0.05 \pm 0.01 \\
\text { e }\end{array}$ & $\begin{array}{c}0 \pm 0 \\
f\end{array}$ & $\begin{array}{c}0 \pm 0 \\
f\end{array}$ \\
\hline $\mathrm{CuSO}_{4}$ & $\begin{array}{c}2.00 \pm 0.09 \\
a\end{array}$ & $\begin{array}{c}1.1 \pm 0.12 \\
\text { b }\end{array}$ & $\begin{array}{c}0.2 \pm 0 \\
\text { c }\end{array}$ & $\begin{array}{c}0.01 \pm 0 \\
\text { c }\end{array}$ & $\begin{array}{c}0 \pm 0 \\
\text { d }\end{array}$ & $\begin{array}{c}0 \pm 0 \\
\text { d }\end{array}$ & $\begin{array}{c}0 \pm 0 \\
\text { d }\end{array}$ \\
\hline \multirow{2}{*}{ Metal Salts } & \multicolumn{7}{|c|}{ Inhibition of mycelial growth (\%) of $A$. altermata } \\
\hline & 25 ppm & 50 ppm & 75 ppm & $80 \mathrm{ppm}$ & 85 ppm & 90 ppm & 100ppm \\
\hline $\mathrm{CuCl}_{2}$ & $31 \mathrm{~g}$ & $52 f$ & $80 e$ & $87 d$ & $96 c$ & $99 b$ & $100 a$ \\
\hline $\mathrm{CuNO}_{3}$ & $61 e$ & $72 d$ & $81 c$ & $90 b$ & $99.1 \mathrm{a}$ & $100 a$ & $100 a$ \\
\hline $\mathrm{CuSO}_{4}$ & $72 d$ & $85 c$ & $98 b$ & $99 b$ & $100 a$ & $100 a$ & $100 a$ \\
\hline
\end{tabular}

Note: Inhibition in mycelial growth (\%) was calculated using mean values of radial growth of the fungus.

Data are the mean values of $n=3$. In rows values with the different letters show significant difference $(P \leq 0.05)$ as determined by Duncan's Multiple Range Test.

\subsection{Fungus growth assays with copper sulphate in broth}

Metal-fungus interaction in broth revealed that fresh and dry biomass of fungal mycelium was significantly reduced by $40-90 \%$ and $70-99 \%$, respectively with the increase in concentration of $\mathrm{CuSO}_{4}$ ( 25 to 100 ppm) (Figure 1). However, the reduction in biomass was not consistent with increase in metal concentration, as the fungus uptake $40 \%$ of the metal at each of the four concentrations. There was directly proportional relationship between metal uptake by the fungus and residual metal concentration in the medium (Figure 2).

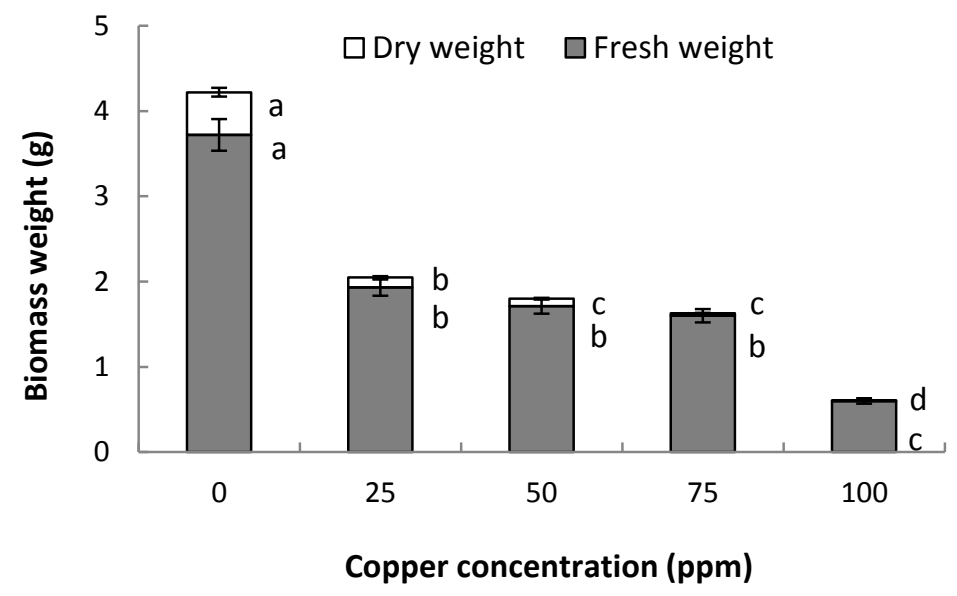

Figure 1. Effect of $\mathrm{Cu}(\mathrm{II})$ on the biomass production of Alternaria alternata 
Vertical bars show standard errors of means of three replicates. Bar fragments with different letters show significant difference $(\mathrm{P} \leq 0.05)$ as determined by Duncan's Multiple Range Test.

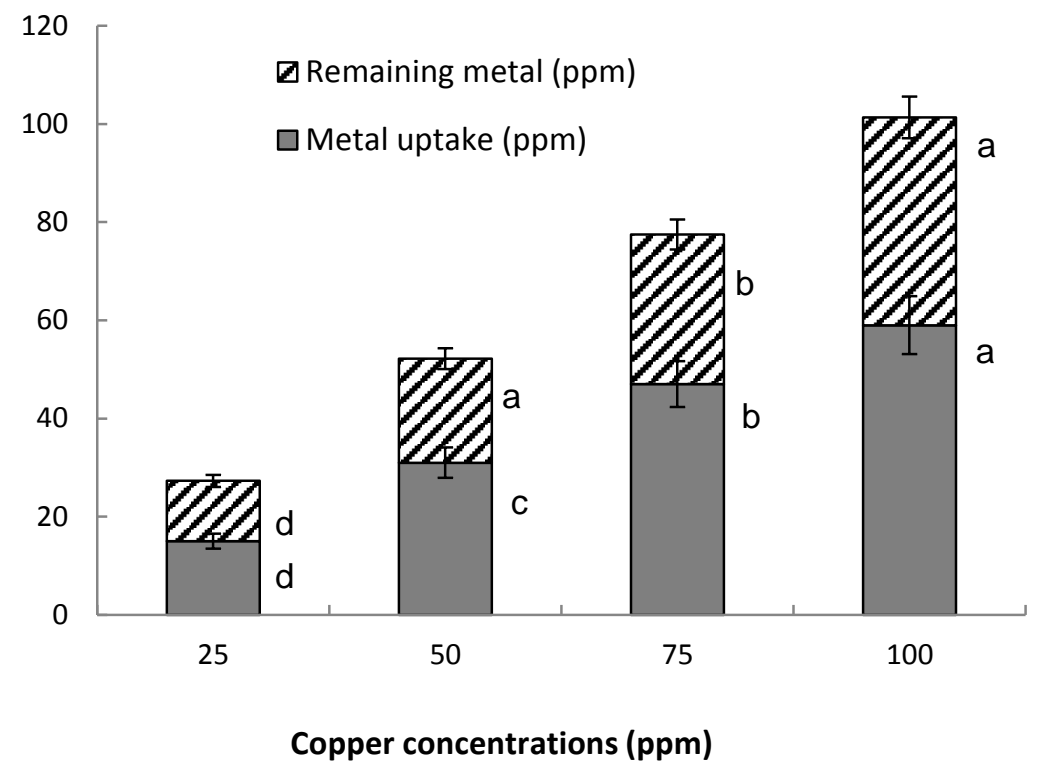

Figure 2. Effect of $\mathrm{Cu}(\mathrm{II})$ on metal uptake by biomass of Alternaria alternata

Vertical bars show standard errors of means of three replicates. Bar fragments with different letters show significant difference $(\mathrm{P} \leq 0.05)$ as determined by Duncan's Multiple Range Test.

Similar results were recorded by Gomaa and Azab (2013), while evaluating effect of Cu on growth of Aspergillus flavus. Fourest and Rox (1992) reported that metal ions uptake per gram of biosorbent increases as long as the biosorbent is not saturated. Quick occupation of absorption sites due to the high surface loading caused by the high metal concentration would result in a fall in metal ions entrance of into the deep pores and thus the metal uptake is reduced (Vadkertiova and Slavikova, 2006). Besides, Cu/Zn superoxide dismutase, may help in buffering $\mathrm{CU}$ (II) concentrations by adding superfluous free Cu(II) (Avery and Avery, 2001) and catalyzing conversion of superoxide to peroxide and oxygen.

\subsection{Fungus protein and enzyme assays with copper sulphate in broth}

The dynamics of the total protein content and catalase activity in the fresh mycelium was recorded at three time intervals (48, 72 and 96 hours) after inoculation and at four i.e. 25, 50, 75 and 100 ppm metal concentrations. Both protein contents and catalase activity of the fungus was significantly increased by $100-$ $500 \%$ and $50-300 \%$, respectively with increase in metal concentration from 25 to 100 ppm over control. Likewise, protein content and catalase activity was also increased with increased in incubation periods of the fungus both in control as well as in metal-amended treatments, however the maximum increase in both parameters was observed after 48 hours of incubation (Table $2 \& 3$ ).

Acceleration in proteins content and catalytic activity may be induced by exposure of the cells to elevated levels of hydrogen peroxide and both may facilitate in metabolization of reactive oxygen species in peroxysomes (Ercal et al., 2001). While, it has been documented that increase degradation and oxidation of damaged proteins can form aggregates and harm cells (Cabiscol et al., 2000). Activity of CAT could be due to activation of antioxidant defense system acting against oxidative stress (Masto et al., 2011). The observed protein content and catalase activity is well-related with acute metal treatment and oxidative stress in fungal cells. Although level of CAT was increased to overcome deleterious effect of copper, but reduction in fungus 
growth clearly indicted negative impact of copper, probably mediated by the overloading of antioxidant defenses (Krumova et al., 2012).

Table 2. Effect of $\mathrm{Cu}(\mathrm{II})$ metal on total protein content $\left(\mathrm{mg} \mathrm{g}^{-1} \mathrm{FW}\right)$ of Alternaria alternata at different intervals of time

\begin{tabular}{|c|c|c|c|}
\hline Metal treatments (ppm) & $\mathbf{4 8} \mathbf{h r s}$ & $\mathbf{7 2} \mathbf{h r s}$ & $\mathbf{9 6} \mathbf{h r s}$ \\
\hline $\mathbf{0}$ & $0.42 \pm 0.15 \mathbf{e}$ & $0.64 \pm 0.11 \mathbf{e}$ & $0.67 \pm 0.13 \mathbf{e}$ \\
\hline $\mathbf{2 5}$ & $1.23 \pm 0.16 \mathbf{d}$ & $1.45 \pm 0.13 \mathbf{d}$ & $1.57 \pm 0.08 \mathbf{d}$ \\
\hline $\mathbf{5 0}$ & $1.71 \pm 0.12 \mathrm{c}$ & $2.11 \pm 0.10 \mathbf{c}$ & $2.58 \pm 0.15 \mathbf{c}$ \\
\hline $\mathbf{7 5}$ & $2.2 \pm 0.10 \mathbf{b}$ & $2.54 \pm 0.09 \mathbf{b}$ & $2.93 \pm 0.16 \mathbf{b}$ \\
\hline $\mathbf{1 0 0}$ & $2.69 \pm 0.13 \mathbf{a}$ & $2.99 \pm 0.15 \mathbf{a}$ & $3.21 \pm 0.17 \mathrm{a}$ \\
\hline LSD & $\mathbf{1 . 9 9}$ & $\mathbf{2 . 0 1}$ & $\mathbf{2 . 5 3}$ \\
\hline
\end{tabular}

Data are the mean values of $n=3$. In a column values with the different letters show significant difference $(P \leq$ $0.05)$ as determined by Duncan's Multiple Range Test.

Table 3. Effect of $\mathrm{Cu}(\mathrm{II})$ metal on catalytic activity $\left(U \mu \mathrm{mol}^{-1} \mathrm{~min}^{-1} \mathrm{mg}\right.$ protein) of Alternaria alternate at different intervals of time

\begin{tabular}{|c|c|c|c|}
\hline Metal treatments (ppm) & $\mathbf{4 8} \mathbf{h r s}$ & $\mathbf{7 2} \mathbf{h r s}$ & $\mathbf{9 6} \mathbf{h r s}$ \\
\hline $\mathbf{0}$ & $0.8 \pm 0.05 \mathbf{e}$ & $1.3 \pm 0.11 \mathrm{e}$ & $1.7 \pm 0.09 \mathrm{e}$ \\
\hline $\mathbf{2 5}$ & $1.68 \pm 0.09 \mathbf{d}$ & $1.9 \pm 0.16 \mathbf{d}$ & $2.3 \pm 0.17 \mathrm{~d}$ \\
\hline $\mathbf{5 0}$ & $2.45 \pm 0.17 \mathrm{c}$ & $2.8 \pm 0.13 \mathrm{bc}$ & $2.99 \pm 0.13 \mathrm{c}$ \\
\hline $\mathbf{7 5}$ & $3.1 \pm 0.21 \mathbf{b}$ & $3.5 \pm 0.22 \mathrm{~b}$ & $3.8 \pm 0.20 \mathrm{~b}$ \\
\hline $\mathbf{1 0 0}$ & $3.5 \pm 0.24 \mathrm{a}$ & $3.9 \pm 0.21 \mathrm{a}$ & $4.1 \pm 0.25 \mathrm{a}$ \\
\hline LSD & $\mathbf{1 . 2 2}$ & $\mathbf{1 . 1 5}$ & $\mathbf{1 . 3 8}$ \\
\hline
\end{tabular}

Data are the mean values of $n=3$. In a column values with the different letters show significant difference $(P \leq$ $0.05)$ as determined by Duncan's Multiple Range Test.

\section{Conclusions}

The radial growth of $A$. alternata was very sensitive to sulphate of copper than nitrate and chloride. However, the fungus can tolerate up to $90 \mathrm{ppm}$ of the metal. Copper sulphate not only inhibited biomass production of the fungus but also increased total protein contents and catalase activity due to increase in metal concentration from 25-100 ppm and incubation period from 48, 72 and 96 hours. Therefore, in future it is necessary to investigate fungus metal tolerance range during fungicide formulations and to explore research focusing on metal-pathogen interaction when crops are vulnerable to disease.

Acknowledgment

We highly acknowledge The University of the Punjab for providing funding to accomplish current research work.

\section{References}

Abe F., Miura T., Nagahama T., Inoue A., Usami R. and Horikoshi K. (2001), Isolation of highly copper-tolerant yeast, Cryptococcus sp., from the Japan Trench and the induction of superoxide dismutase activity by $\mathrm{Cu}^{2+}$, Biotechnol Lett, 23, 2027-2034.

Al-Abboud M.A. and Alawlaqi M.M. (2011), Biouptake of copper and their Impact on fungal fatty acids, Aust J Basic Appl Sci, 5, 283-290.

Avery A.M. and Avery S.V. (2001), Saccharomyces cerevisiae expresses three phospholipid hydroperoxide glutathione peroxidases. J Biol Chem, 276, 33730-33735. 
Borkow G. and Gabbay J. (2009), Copper, an ancient remedy returning to fight microbial. Fungal and Viral Infections, Curr Chem Biol, 3, 272-278.

Cabiscol E., Tamarit J. and Ros J. (2000), Oxidative stress in bacteria and protein damage by reactive oxygen species, Int Microbiol, 3, 3-8.

Chander K. and Brookes P.C. (1991), Effects of heavy metals from past applications of sewage sludge on microbial biomass and organic matter accumulation in a sandy loam soil and silty loam UK soil, Soil Biol Biochem, 23, 927-932.

Choudhary M., Jetley U.K., Khan M.A., Zutshi S. and Fatma T (2007), Effect of heavy metal stress on proline, malondialdehyde and superoxide dismutase activity in the Cyanobacterium Spirulina platensis-S5, Ecotoxicol Environ Saf, 66, 204-209.

Clemens S., Bloss T., Vess C., Neumann D., Nies D.H. and Z-Nieden U. (2002), A transporter in the endoplasmic reticulum of Schizosaccharomyces pombe cells mediates zinc storage and differentially affects transition metal tolerance, J Biol Chem, 277, 18215-18221.

Collin-Hansen C., Andersen R.A. and Steinnes E. (2005), Molecular defense systems are expressed in the king bolete (Boletus edulis) growing near metal smelters, Mycologia, 97, 973-983.

Cornejo P., Pérez-Tienda J., Meier S., Valderas A., Borie F., Azcón-Aguilar C. and Ferrol N. (2013), Copper compartmentalization in spores as a survival strategy of arbuscular mycorrhizal fungi in Cu-polluted environments, Soil Biol Biochem, 57, 925-928.

Duarte S., Pascoal C. and Cassio F. (2004), Effects of zinc on leaf decomposition by fungi in streams: studies in microcosms, Microb Ecol, 93, 366-374.

Ercal N., Gurer-Orhan H. and Aykin-Burns N. (2001), Toxic metals and oxidative stress part I: Mechanisms in volved in metal induced oxidative damage, Curr Top Med Chem, 1, 529-539.

Fourest E. and Roux J.C. (1992), Heavy metal biosorption by fungal mycelial by-products: mechanisms and influence of $\mathrm{pH}$, Appl Microbiol Biotechnol, 3, 399-403.

Furat Ö. and Kargin F. (2010), Effects of Zinc and Cadmium on Erythrocyte Antioxidant Systems of a Freshwater Fish Oreochromis niloticus, J Biochem Mol Toxicol, 24, 223-229.

Gadd G.M. (1993), Interactions of fungi with toxic metals, New Phytol, 124, 25-60.

Gattai G.S., Pereira S.V., Costa C.M.C., Lima C.E.P. and Maia L.C. (2011), Microbial activity, arbuscular mycorrhizal fungi and noculation of woody plants in lead contaminated soil, Braz J Microbiol, 42, 859-867.

Gomaa O.M. and Azab K.S. (2013), Biological indicators, genetic polymorphism and expression in Aspergillus flavus under copper mediated stress, J Radiat Res App/ Sci, 6, 49-55.

Hefnawy M.A., Ali M.I. and Abdul-Ghanay S.A. (2009). Influence of copper and cobalt stress on morphology and ultra structure of Chaetomium Globosum and Stachybotrys Chartarum. Aust J Basic Appl Sci, 3, 3158-3165.

Islam M.S., Ali M. and Rahman M.S. (2011), In vitro studies on the fungicidal effect on Trichoderma species in tea plantation, Bangladesh J Agril Res, 36, 677-683.

Konopka A., Zakharova T., Bischoff M., Oliver L., Nakatsu C. and Turco R.F. (1999), Microbial biomass and activity in leadcontaminated soil, Appl Environ Microbiol, 65, 2256-2259.

Levinskaite L. (2001), Fungi of the genus Penicillium under the influence of heavy metals. Metal-tolerance of various isolates, Bot Lith, 7, 79-91.

Lowry O.H., Rosenbrough N.J., Farr A.L. and Randall R.J. (1951), Protein measurement with the Folin phenol reagent, $J$ Biol Chem, 193, 265-275.

Masto R.E., Ahirwar R., George J., Ram LC. and Selvi VA. (2011), Soil Biological and Biochemical Response to Cd Exposure, Open J Soil Sci, 1, 8-15.

Mehta K.D., Chitrangada D., Rakesh K., Pandey B.D. and Mehrotra S.P. (2010), Effect of mechano-chemical activation on bioleaching of Indian Ocean nodules by a fungus, Min Eng, 23, 1207-1212. 
Miersch J., Tschimedbalshir M., Barlocher F., Grams Y., Pierau, B., Schierhorn A. and Krauss G.J. (2001), Heavy metals and thiol compounds in Mucor racemosus and Articulospora tetracladia, Mycol Res, 105, 883-889.

Oliveira A. and Pampulha M.E. (2006), Effects of long-term heavy metal contamination on soil microbial characteristics, J Biosci Bioeng, 102,157-161.

Pečiulytė D. and Dirginčiutè-Volodkienè V. (2012), Effect of zinc and copper on cultivable populations of soil fungi with special reference to entomopathogenic fungi, Acad J, 58, 65.

Petr B. (2010), Effect of heavy metals on saprotrophic soil fungi, Soil Biol, 19, 263-279.

Plum L.M., Rink L. and Haase H. (2010), The Essential Toxin: Impact of Zinc on Human Health, Int J Environ Res Publ Health, 7, 1342-1365.

Rudawska M., Kieliszewska-Rokicka B. and Leski T. (2000), Effect of aluminium on Pinus sylvestris seedlings mycorrhizal with aluminium-tolerant and aluminium-sensitive strains of Suillus luteus, Dendrobiology, 45, 89-96.

Shoaib A., Aslam N. and Aslam N. (2013), Trichoderma harzianum: Adsorption, desorption, isotherm and FTIR studies, J Anim Plant Sci, 23, 1460-1465.

Sinha A.K. (1972), Colorimetric assay of catalase, Anal Biochem, 47, 389-394.

Steel R.G.D., Torrie J.H. and Dickey D.A. (1997). Principles and Procedures of Statistics. A biometrical approach. 3rd Ed., McGraw Hill Book Co., New York, USA.

Vadkertiova R. and Slavikova E. (2006), Metal tolerance of yeasts isolated from water, soil and plant environments, J Basic Microbiol, 46, 145-152.

Yruela I. (2009), Copper in plants: acquisition, transport and interactions, Funct Plant Biol, 36, 409-430. 